nghiên cứu biến đổi hình thái của gan chuôt cống trắng khi nhiễm độc cấp thuốc trừ sâu Bassa đã được công bố năm 2001. Ở lô chuột thực nghiệm có sự thay đổi hình thái các tế bào gan và lượng lipid trong bào tương các tế bào gan, các tế bào nhiều lipid tập trung chủ yếu ở ngoại vi của tiểu thùy gan và lượng lipid trong bào tương tế bào giảm dân theo thời gian chuột được uống nước sắc lá sen khô, chứng tỏ nước lá sen khô có tác dụng đối với việc giảm mõ trong gan. Tuy nhiên, các nghiên cứu về lá sen trong việc giảm lượng mõ có trong gan vẫn đang được các nhà khoa học nghiên cứu, môt nghiên cứu khác trên chuột cũng cho thấy lượng cholesterol toàn phần trong huyết thanh và gan, cholesterol tứ do và phospholipids so với nhóm đối chứng chứa nhiều chất béo giảm manh. Ngoài ra, Flavonoid chất chiết xuất từ lá sen khô này còn làm giảm tổn thương gan do lượng lipid nhiều gây ra, điều này giải thích kết quả nghiên cứu của chúng tôi không thấy hình ảnh tế bào gan bị phá hủy, tổn thương.

\section{KẾT LUẬN}

Từ kết quả nghiên cứu thực nghiêm trên chuột cống trắng cho thây có sự thay đổi lượng lipid trong bào tương tế bào gan chuột khi uống nước sắc lá sen khô. Lượng lipid giảm dần theo số ngày chuột được uống nước sắc lá sen.

\section{TÀI LIÊU THAM KHẢO}

1. Bùi Thanh Thủy (2001), Nghiên cứu biến đổi hình thái gan chuột cống trắng sau nhiễm thuốc trừ sâu Bassa, Luận văn cao học, Trường Đại học Y Hà Nôi.

2. Bùi Thanh Thủy, Nguyễn Thị Hiệp Tuyết (2011), Nghiên cứu cẩu trúc mô học gan chuột nhiễm độc cấp thuốc trừ sâu nhóm carbamat sau giải độc bằng cam thảo lục đậu thang, Tạp chí Khoa học \&Công nghệ Đại học Thái Nguyên, tập 89, Số (01)/2, 2012.

3. Jiali Liu, Lina Han, Leilei Zhu, Yerong Yu (2016), Free fatty acids, not triglycerides, are associated with non-alcoholic liver injury progression in high fat diet induced obese rats. Lipids Health Dis. 2016 Feb 11;15:27

4. Joost Willebrords, Isabel Veloso Alves Pereira, Michaël Maes, Sara Crespo Yanguas, Isabelle Colle, Bert Van Den Bossche, Tereza Cristina Da Silva, Cláudia Pinto Marques Souza de Oliveira, Wellington Andraus, Venâncio Avancini Álves, Bruno Cogliati, Mathieu Vinken (2015), Strategies, models and biomarkers in experimental non-alcoholic fatty liver disease research. Prog Lipid Res. 2015 Jul;59:106-25.

\title{
PHÁT HIÊN DNA MYCOBACTERIUM TUBERCULOSIS TRONG MẪU PHẾT NIÊM MẠC MIỆNG VỚI KỸ THUÂTT REAL-TIME PCR TRONG CHẨN ĐOÁN LAO PHỔI
}

\section{TÓM TẮT}

Mục tiêu: Xác định giá trị chẩn đoán của xét nghiệm phát hiện DNA Mycobacterium tuberculosis trong mâ̂u phết niêm mạc miệng của bệnh nhân nghi ngờ mắc lao phổi bằng kỹ thuật real-time $P C R$ và phân tích một số yếu tố liên quan. Đối tượng và phương pháp nghiên cứu: Nghiên cứu mổ tả cắt ngang được thực hiện trên 85 bệnh nhân là người trưởng thành, nghi ngờ mắc lao phổi. Phát hiện DNA

${ }^{1}$ Đại học Y Dược Thành phố Hồ Chí Minh

${ }^{2}$ Trường Đại học Y Dược Cần Tho

${ }^{3}$ Bênh viẹn Phạm Ngọc Thach

${ }^{4}$ Trung tâm Kiểm chuẩn chất lượng xét nghiệm y học, Bộ Y tế, Đai hoc Y Dượ TP. HCM.

Chịu trách nhiệm chính: Vũ Quang Huy

Email: drvuquanghuy@gmail.com

Ngày nhận bài: 4.3.2021

Ngày phản biên khoa hoc: 23.4.2021

Ngày duyệt bài: 4.5.2021
Trần Phước Thịnh ${ }^{1,2}$, Nguyễn Hữu Lân ${ }^{3}$, Lê Văn Chương1,4, Vũ Quang Huy ${ }^{1,4}$

Mycobacterium tuberculosis trong mẫu phết niêm mạc miệng bằng kỹ thuật real-time PCR và so sánh với xét nghiệm Xpert MTB/RIF Ultra (Xpert MTB) mẫu đàm. Kết quả: Độ nhạy và độ đặc hiệu của mẫu phết niêm mạc miệng là $74,4 \%$ và $100 \%$. Mật độ vi khuẩn thấp, ăn uống trước lấy mẫu là những yếu tố có liên quan đến sự âm tính giả của mẫu phết niêm mạc miệng. Ở những bệnh nhân phải lấy đàm kích thích hoặc nộp đàm trế thì mẫu phết niêm mạc miệng cũng phát hiện DNA vi khuẩn ở 10/14 và 9/12 trường hợp theo thứ tự tương ứng. Kết luân: Nghiên cứu đã cho thấy tính khả thi của mẫu phết niêm mạc miệng và tiềm năng bổ sung cho mẫu đàm nhằm cải thiến về thời gian chẩn đoán và giảm tỷ lệ bệnh nhân phải chịu một số thủ thuật xâm lấn trong chẩn đoán lao phổi.

Tư khóa: Lao phổi, phết niêm mạc miệng, realtime PCR, Xpert MTB/RIF, sinh học phân tử.

\section{SUMMARY \\ DETECTION OF DNA MYCOBACTERIUM TUBERCULOSIS IN ORAL SWAB BY THE}




\section{REAL-TIME PCR TECHNIQUE FOR PULMONARY TUBERCULOSIS DIAGNOSIS}

Objectives: Determination of the diagnostic value of detection of Mycobacterium tuberculosis DNA in the oral swab of patients who were suspected of having pulmonary tuberculosis by real-time PCR and analysis of several related factors. Methods and Materials: A cross-sectional study was conducted on 85 adult patients who suspected of pulmonary tuberculosis. Detect DNA Mycobacterium tuberculosis in samples of oral swab by real-time PCR and compare this to the sputum testing - Xpert MTB / RIF Ultra (Xpert MTB). Results: The sensitivity and specificity of oral swab sample were $74,4 \%$ and $100 \%$. The patients with low loading of bacteria as well as eating, drinking before collecting sample could affect to the ability to detect DNA Mycobacterium tuberculosis in oral swab. Patients who could not expectorate sputum at the time of examination must spray aerosol for induced sputum or submit sputum later (1-3days). The sample of oral swab also detected bacterial DNA in $10 / 14$ cases in a group using the aerosol spray and 9/12 in a group of late applying sputum. Conclusions: Preliminary research has identified the ability to detect tuberculosis bacterial DNA in oral swab with a significant proportion and high specificity. This sampling method has the potential to complement for sputum samples to reduce diagnostic time and the proportion of patients who suffer from some invasive procedures.

Keywords: Pulmonary tuberculosis, oral swab, real-time PCR, Xpert MTB/RIF, molecular biology.

\section{I. ĐẠTT VẤN ĐỀ}

Đàm là mẫu bệnh phẩm thường quy trong các xét nghiệm chẩn đoán lao phổi. Tuy nhiên việc thu thập mẫu đàm thường gặp phải một số thử thách như bênh nhân không thể ho, khac được mẫu đàm hoặc chỉ thu được mẫu đàm kém chất lượng [4], [5]. Nhiều nghiên cứu trước đây về các mầu bệnh phẩm như hơi thở, nước bọt, máu, nước tiểu và phân để xác định vi khuẩn lao đã được thực hiện nhưng hiệu quả vẫn còn ở mức hạn chế [1], [5]. Gần đây một số nghiên cứu về mẫu phêt niêm mạc miệng cho thấy với đăc điểm dễ lấy, an toàn, ít xâm lấn, chi phí thấp và dễ dàng đồng bộ trong việc thu thập cũng như xử lý mấu, có tính khả thi để bổ sung hoặc thay thế mẫu đàm trong chẩn đoán lao phổi [2], [3], [6]. Để thực hiện bước đầu trong việc kiểm chứng tính khả thi của mẫu niêm mạc miệng trong điều kiện thực tế chẩn đoán lao phổi chúng tôi thực hiện nghiên cứu này với mục tiêu: Xác định giá trị chẩn đoán của xét nghiệm phát hiện DNA Mycobacterium tuberculosis trong mẫu phêt niêm mac miệng của bệnh nhân nghi ngờ mắc lao phổi bằng kỹ thuật real-time $P C R$ và phân tích mốt số yếu tố liên quan có thể gây âm tính giả mẫu phết niêm mạc miệng.

\section{I. ĐỐI TƯƠNGG VÀ PHƯƠNG PHÁP NGHIÊN CỨU}

2.1. Đối tượng nghiên cứu. Nghiên cứu được thực hiện trên bệnh nhân trên 18 tuổi, có triệu chứng nghi ngờ mắc lao phổi đến khám tại Bệnh viện Phạm Ngọc Thạch từ tháng 2 đển tháng 4 năm 2020.

\subsection{Phương pháp nghiên cứu}

Thiết kế nghiên cứu: Nghiên cứu mô tả cắt ngang với phương pháp lấy mẫu thuận tiện không xác suất, tất cả những bệnh nhân đủ tiểu chuẩn nghiên cứu đều có thể được lựa chọn đưa vào nghiên cứu.

\section{Phương pháp thu thập số liêu}

- Bênh nhân có triêuu chứng nghi ngờ mắc lao phổi xác định qua các triệu chứng lâm sàng hoặc hình ảnh Xquang ngực theo Hướng dẫn của Chương trình chống lao Quốc gia.

- Tiến hành lấy 01 mấu phết niêm mac miệng ngay trước khi bệnh nhân được hướng dẫn đi lây mẫu đàm.

- Ghi nhân kết quả xét nghiêm đàm (Xpert MTB và soi nhuộm AFB trực tiếp) và phương pháp lấy mẫu đàm đã thực hiện.

\subsection{Kỹ thuật lấy và xử lý mẫu phết niêm} mạc miệng

- Yêu cầu bệnh nhân mở miệng, đưa lưỡi ra phía trước và hạ thấp để lộ rõ phần niêm mạc miệng vùng $1 / 3$ sau mặt lưng lưỡi, dùng tăm bông vô trùng Rayon vừa chà xát vừa phải vừa xoay đều đặn đầu tăm bông khoảng 7-8 giây tương đương 10 lần chà xát để thu thập tế bào bám trên niêm mạc miệng, cho que tăm bông vào tube chứa và đậy kín nắp.

- Mẫu phết niêm mac miệng sau khi lấy được bảo quản ngay ở nhiệt độ $2-8^{\circ} \mathrm{C}$ trong điểu kiện khô cho đến khi được ly trích DNA toàn bộ (không quá 24 giờ kể từ lúc lấy mẫu).

\subsection{Xét nghiệm real-time PCR mẫu phết} niêm mạc miệng (01 mấu)

Mẫu phết niêm mac miêng được ly trích acid nucleic toàn bô, sản phẩm ly trích được đưa vào phản ứng real-time PCR khuếch đại một đoạn đăc hiêu dài $249 \mathrm{bp}$ từ đọn chèn IS6110 hiền diện với khoảng 16-25 copies trên genome của Mycobacterium tuberculosis. Các đoạn gen đích được phát hiện sau mỗi chu kì nhân lên trong phản ứng bằng đoạn dò có gắn chất phát huỳnh quang (Taqman probe).

\subsection{Các xét nghiệm đàm ( 03 mẫu)}

- Xét nghiệm AFB trực tiếp (2 mẫu): xét nghiệm được thực hiện bằng phương pháp nhuộm huỳnh quang và phát hiện AFB dưới kính hiển vi huỳnh quang.

- Xét nghiệm Xpert MTB/RIF Ultra (1 mẫu): 
xét nghiêm dựa trên phản ứng hemi-nested realtime PCR với đoạn đích để xác định sự có mặt của Mycobacterium tuberculosis là đoạn IS 6110 và đoan IS 1081.

2.6. Quản lý và xử lý số liêu. Nhâp dữ liêu trên phần mềm Excel. Xử lý thống kê dữ liệu bằng phần mềm $\mathrm{R}$ (version 3.6.3).

\section{KẾT QUẢ NGHIÊN CỨU}

Trong thời gian từ tháng 2 đến tháng 4 năm 2020 tại Khoa Khám và Điều trị ngoại trú, Bệnh viện Phạm Ngọc Thạch, Thành phố Hồ Chí Minh, chúng tôi thu nhận và phân tích 85 trường hợp trong nghiên cứu này.

3.1. Đặc điểm dân số nghiên cứu. Độ tuổi trung bình của dân số nghiên cứu là 44,9 tuổi ( \pm $16,4)$, thấp nhất là 19 và cao nhất là 80 . Về nghề nghiệp, nghề tự do có tỉ lệ cao nhất với $38,8 \%$, kế đến là nhóm nghề công nhân và nông dân, mỗi nhóm chiếm khoảng $20 \%(21,2 \%$ và $17,6 \%$, nhóm nhân viên, sinh viên và nhóm nghề khác mỗi nhóm chiếm khoảng $10 \%$ còn laai.

Dựa vào kết quả xét nghiệm Xpert MTB mẫu đàm có 43 bệnh nhân được chẩn đoán xác định mắc lao phổi, tỉ lệ 50,6\% (43/85).

3.2. Giá trị phát hiện DNA Mycobacterium tuberculosis trong mẫu phết niêm mạc

\section{miêng trong chẩn đoán lao phổi}

3.2.1. Tỉ lệ phát hiện chung. Trong tổng số 85 trường hợp nghi ngờ mắc lao phổi chúng tôi xác định được 32 trường hợp $(31,8 \%)$ dương tính với xét nghiệm real-time PCR phát hiên DNA vi khuẩn lao trong mẫu phết niêm mạc miệng.

3.2.2. Giá trị độ nhạy, độ đặc hiệu, giá trị tiên đoán dương và giá trị tiền đoán âm so với mẫu đàm. Chúng tôi sử dụng kết quả xét nghiêm Xpert MTB mẩu đàm làm tiêu chuẩn chẩn đoán và xác định các độ nhạy, độ đặc hiệu, giá trị tiên đoán dương và giá trị tiên đoán âm của mẫu phết niêm mạc miệng lần lượt là $74,4 \%, 100 \%, 100 \%$ và $79,2 \%$ (Bảng 1).

Bảng 1. So sánh kêt quả xét nghiệm real-time PCR mấu phết niềm mac miểng và kêt quả xét nghiệm Xpert MTB mẫu đàm $(n=85)$

\begin{tabular}{|c|c|c|c|}
\hline \multicolumn{2}{|c|}{} & \multicolumn{2}{|c|}{ Kết quả Xpert MTB } \\
\cline { 3 - 4 } \multicolumn{2}{|c|}{} & $\begin{array}{c}\text { Dương } \\
\text { tính } \\
(\mathbf{n = 4 3 )}\end{array}$ & $\begin{array}{c}\text { Âm tính } \\
\mathbf{( n = 4 2 )}\end{array}$ \\
\hline $\begin{array}{c}\text { Real-time } \\
\text { PCR phết } \\
\text { niêm mạc } \\
\text { miệng }\end{array}$ & $\begin{array}{c}\text { Dương tính } \\
(n=32)\end{array}$ & 32 & 0 \\
\cline { 2 - 4 } & $\begin{array}{c}\text { Âm tính } \\
(n=53)\end{array}$ & 11 & 42 \\
\hline
\end{tabular}

3.2.3. Giá trị của mẫu phết niêm mạc miệng khi bệnh nhân không thể ho khạc đàm tự nhiên tại thời điểm khám

Bảng 2. So sánh kết quả xét nghiệm mẫu phêt niêm mạc miệng và mẫu đàm theo các phương pháp lấy mẫu đàm

\begin{tabular}{|c|c|c|c|c|}
\hline \multirow{2}{*}{ Phương pháp lấy mẫu đàm } & \multicolumn{2}{|c|}{ Xpert MTB $(n=85)$} & \multicolumn{2}{|c|}{$\begin{array}{c}\text { Phết niêm mạc miệng } \\
(\mathrm{n}=\mathbf{8 5})\end{array}$} \\
\hline & $\begin{array}{l}\text { Dương tính } \\
(n=43)\end{array}$ & $\begin{array}{c}\text { Ām tính } \\
(n=42)\end{array}$ & $\begin{array}{l}\text { Dương tính } \\
(n=32)\end{array}$ & $\begin{array}{l}\text { Ám tính } \\
(n=53)\end{array}$ \\
\hline Lấy đàm kích thích ( $\mathrm{n}=27$ ) & 14 & 13 & 10 & 17 \\
\hline Lấy đàm tự nhiên $(\mathrm{n}=58)$ & 29 & 29 & 22 & 36 \\
\hline Trong buối khám $(n=36)$ & 17 & 19 & 13 & 23 \\
\hline $\begin{array}{c}\text { Nhận lọ chứa đàm về và nộp sau } \\
(n=22)\end{array}$ & 12 & 10 & 9 & 13 \\
\hline
\end{tabular}

Xét các trường hợp không thể lấy được mẫu đàm tại thời điểm khám, có 27 trường hợp được chỉ định phun khí dung để lấy đàm kích thích. Kết quả có 14 trường hợp dương tính với xét nghiệm Xpert MTB mẫu đàm, trong số 14 trường hợp đó mẫu phết niêm mạc miệng cũng đã phát hiện được 10 trường hợp $(71,4 \%)$. Bên cạnh đó cũng có 22 trường hợp mang lọ chứa đàm để ho khạc tại nhà và nộp lại sau. Kết quả có 12 trường hợp dương tính với xét nghiệm mẫu đàm, và mẩu phết niêm mạc miệng phát hiện được 9 trường hợp (75\%).

3.3. Phân tích một số yếu tố liên quan đến sư âm tính giả của mẫu phết niêm mạc miệng so với xét nghiệm Xpert MTB. Trong 43 bệnh nhân có kết quả Xpert MTB dương tính, có 11 trường hợp không phát hiện DNA vi khuẩn lao trong mấu niêm mạc miệng (âm tính giả) và phát hiện được 32 trường hợp còn lại (dương tính thật). Kết quả đánh giá mối liên quan đến sự âm tính giả của mẫu phết niêm mạc miệng:

3.3.1. Mật độ vi khuẩn trong mẫu đàm. Sự ảnh hưởng mật độ vi khuẩn trong mẫu đàm đến sự âm tính giả của mẫu phết niêm mạc miệng được đánh giá thông qua kết quả AFB trực tiếp mẫu đàm, vì ở bệnh nhân có mật độ vi 
khuẩn thấp thường biểu hiện ở kết quả xét nghiệm AFB âm tính.

Tỷ lệ âm tính giả ở nhóm bệnh nhân có kết quả $A F B$ âm tính là $87,5 \%(7 / 8)$ và ở nhóm có ít nhất một mẫu đàm AFB dương tính là $11,4 \%$ (4/35) (Bảng 3), sự khác biệt này có ý nghĩa thống kê với $P<0,001$ qua phép kiểm Chi bình phương.

Bảng 3. Phân bố kêt quả xét mầu phêt niêm mạc miệng theo kêt quả nhuộm soi AFB trực tiếp của nhóm bệnh nhân mắc lao.

\begin{tabular}{|c|c|c|}
\hline \multirow{2}{*}{} & \multicolumn{3}{|c|}{$\begin{array}{c}\text { Nhóm bệnh nhân có kết } \\
\text { quả Xpert dương tính } \\
(\mathbf{n = 4 3 )}\end{array}$} \\
\cline { 2 - 3 } & $\begin{array}{c}\text { Mâ̂́u phết } \\
\text { niêm mạc } \\
\text { miêng âm } \\
\text { tính }(\mathrm{n}=11)\end{array}$ & $\begin{array}{c}\text { Mấu phết niêm } \\
\text { mạc miệng } \\
\text { dương tính } \\
(\mathrm{n}=32)\end{array}$ \\
\hline $\begin{array}{c}\text { AFB âm tính } \\
(\mathrm{n}=8)\end{array}$ & 7 & 1 \\
\hline $\begin{array}{c}\text { AFB dương } \\
\text { tính }(\mathrm{n}=35)\end{array}$ & 4 & 31 \\
\hline
\end{tabular}

3.3.2. Yếu tố ăn uống trước khi lấy mẫu và bệnh lý đái tháo đường

Trong nghiên cứu này chúng tôi loại ra những bệnh nhân đã ăn uống, vệ sinh răng miệng trong vòng 30 phút trước khi lấy mẫu, ở những bệnh nhân được thu dung vào nghiên cứu chúng tôi ghi nhận thời gian ăn uống cách lúc lấy mẫu dao động từ 45 phút cho đến 180 phút. Ngoài ra yếu tố đang điều trị bệnh lý đái tháo đường (làm thay đổi niêm mạc miệng, giảm tiết nước bọt khiến niêm mạc miệng nhạy cảm hơn [7]) cũng được ghi nhận (Bảng 4).

Tỷ lệ âm tính giả của mẫu phết niêm mạc miệng ở nhóm bệnh nhân có ăn uống trước khi lấy mẫu là $57,1 \%(8 / 14)$ và ở nhóm bệnh nhân không ăn uống trước khi lấy mẫu là $10,3 \%$ $(3 / 29)$, sự khác biệt này có ý nghĩa thống kê với $\mathrm{P}=0,003$. Tỷ lệ này ở nhóm bệnh nhân đang điêu trị đái tháo đường và nhóm không điêuu trị đái tháo đường lần lượt là $33,3 \%(2 / 6)$ và $24,3 \%(9 / 37)$, sự khác biệt này không có ý nghĩa thống kê với $\mathrm{P}$ xấp xỉ 1,000 qua phép kiểm Chi bình phương.

Bảng 4. Đánh giá sự ảnh hưởng của yếu tố ăn, uống trước khi lấy mẫu và đang điều trị đái tháo đường đến kêt quả âm tính giả của mấu phêt niêm mạc miệng.

\begin{tabular}{|l|l|l|}
\hline \multirow{2}{*}{} & \multicolumn{2}{|c|}{$\begin{array}{c}\text { Nhóm bếnh nhân có kết } \\
\text { quả Xpert dương tính } \\
(\mathrm{n}=43)\end{array}$} \\
\cline { 2 - 3 } & $\begin{array}{c}\text { Mầu phết } \\
\text { niêm mạc }\end{array}$ & $\begin{array}{c}\text { Mầu phết } \\
\text { niêm mạc }\end{array}$ \\
\hline
\end{tabular}

\begin{tabular}{|c|c|c|c|}
\hline \multicolumn{2}{|c|}{} & $\begin{array}{c}\text { miệng âm } \\
\text { tính (n=11) }\end{array}$ & $\begin{array}{c}\text { miệng dương } \\
\text { tính (n=32) }\end{array}$ \\
\hline $\begin{array}{c}\text { Bê̂nh } \\
\text { nhân } \\
\text { đann }\end{array}$ & Có $(n=6)$ & 2 & 4 \\
\cline { 2 - 4 } $\begin{array}{c}\text { điều trị } \\
\text { đái tháo } \\
\text { đường }\end{array}$ & $\begin{array}{c}\text { Không } \\
(n=37)\end{array}$ & 9 & 28 \\
\hline $\begin{array}{c}\text { Ăn uống } \\
\text { trước khi } \\
\text { lấy mấu }\end{array}$ & $\begin{array}{c}\text { Không } \\
(n=29)\end{array}$ & 3 & 6 \\
\hline
\end{tabular}

\section{BÀN LUÂ̂N}

Về đặc điểm dân số học chúng tôi nhận thấy sự phân bố về độ tuổi và giới tính của dân số trong nghiên cứu này có sự tương đồng với báo cáo của WHO năm 2019 về tình hình bệnh lao tại Việt Nam. Về các đặc điểm lâm sàng trong dân số nghiên cứu của chúng tôi tương đồng với một số nghiên cứu tương tự [2], [8].

Trong nghiên cứu của chúng tôi độ nhạy của xét nghiệm phát hiện DNA trong mẫu niêm mạc miệng khi so sánh với kết quả xét nghiệm Xpert MTB mẫu đàm là $74,4 \%$ thấp hơn so với nghiên cứu của Wood và cs (2015) [6] cho độ nhạy đạt $90 \%$ trên nhóm 20 bệnh nhân (18/20) đã được chẩn đoán xác định với xét nghiệm Xpert MTB mẫu đàm dương tính. Về mặt phương pháp, chúng tôi lấy 1 mẫu phết niêm mạc miệng duy nhất tại thời điểm bệnh nhân nghi lao đến khám, tác giả trên thu thập 3 mẫu phết niêm mac miệng ở các ngày khác nhau, khi bất kì mẫu phết niêm mạc miệng dương tính thì được xác định là dương tính. Nếu chỉ xét 1 mẫu phết niêm mạc miệng đầu tiên của mỗi bệnh nhân trong nghiên cứu trên thì tî lệ phát hiện của nghiên cứu trên là khoảng $60 \%(12 / 20)$. Về mặt kỹ thuật xét nghiệm, tiêu chuân so sánh của chúng tôi là xét nghiệm Xpert MTB thế hệ mới nhất (Xpert MTB/RIF Ultra) với độ nhạy được cải thiên đáng kể và được áp dụng cho nhóm bệnh nhẩn nghi ngờ mắc lao phổi so với kỹ thuật Xpert MTB thế hệ đầu tiên mà tác giả Wood đã sử dụng để chọn những người có mẫu đàm dương tính và sau đó lấy mẫu phết niêm mạc miệng cho nghiên cứu, có thể do những sự khác biệt này nên trong nghiên cứu của chúng tôi bao gồm cả những bệnh nhân có mật độ vi khuẩn thấp và rất thấp.

Luabeya và cs (2020) [2] với thiết kế nghiên cứu cắt ngang tương tự nghiên cứu của chúng tôi trên đối tượng bệnh nhân nghi ngờ mắc lao phổi. Mẫu phết niêm mạc miệng cũng được thực hiện xét nghiệm real-time PCR sử dụng cặp mồi 
đăc hiêu cho đoan chèn IS 6110 của vi khuẩn lao. Kểt quả độ nhạy của mẫu niêm mạc miệng khi so sánh với kết quả xét nghiệm Xpert MTB là $79,6 \%$ (39/49) cho mẫu ngày 1 và $85,7 \%$ (42/49) cho ngày 2 , khi sử dụng kết hợp cả 2 mẫu thì độ nhạy tăng lên đến $91,8 \%(45 / 49)$. Đăc biệt, trong nghiên cứu trên tác giả hướng dẫn bệnh nhân không ăn uống trước khi lấy mẫu ở ngày thứ 2 , điều đó có thể đã làm tăng độ nhạy trong nghiên cứu. Như vậy nếu xác định trên 1 mẫu ngày đầu tiên của tác giả Luabeya và cs thì kết quả nghiên cứu của chúng tôi cũng có sự tương đồng với tác giả.

Tác giả Wood [6] cũng đánh giá về sự âm tính giả của mẫu phết niêm mạc miệng, tác giả nhận thấy có liên quan đến việc đang mắc và điều trị đái tháo đường (cả 2 trường hợp âm tính giả của mẫu phết niêm mạc miệng đều đang mắc và điêu trị đái tháo đường) $(P=0,013)$, yếu tố mật độ vi khuẩn thấp cũng được đánh giá thông qua so sánh tỷ lệ âm tính giả ở nhóm có kết quả nhuộm AFB trực tiếp dương tính và âm tính (đại diện cho nhóm có mật độ vi khuẩn thấp), tác giả ghi nhận không có mối tương quan giữa sự âm tính của xét nghiệm AFB trực tiếp và sự âm tính giả của mẫu phết niêm mạc miệng $(P=0,25)$. Trong nghiên cứu của chúng tôi ghi nhận không có sự liên quan đến tình trạng đang mắc và điều trị đái tháo đường với sự âm tính giả của mẫu phết niêm mac miệng. Đối với ảnh hưởng của mật độ vi khuẩn chúng tôi ghi nhận có mối tương quan giữa mật độ vi khuẩn thấp và sư âm tính giả, điều này không tương đồng với tác giả Wood nhưng lại phù hợp với kết quả nghiên cứu của Lima và cs (2020) [8] khi cho thây độ nhạy của xét nghiệm phát hiện vi khuẩn lao trong mẫu phết niêm mạc miệng giảm dần theo mật độ của vi khuẩn trong mẩu đàm tương ứng. Trong nghiên cứu của chúng tôi cũng ghi nhận sự ảnh hưởng của yếu tố bệnh nhân có ăn uống trước khi lây mẫu phết niểm mạc miệng đến sự âm tính giả, điều này cũng phù hợp với giả thuyết về sự giảm độ nhạy khi mật độ vi khuẩn giảm xuống do việc ăn uống trước đó cũng có thể dẫn đến giảm mật độ vi khuẩn ở niêm mạc miệng của bệnh nhân.

Nghiền cứu của chúng tôi cho thây tính khả thi của việc phát hiện DNA vi khuẩn lao trong mẫu phết niêm mạc miệng. Độ nhạy của mẫu phết niêm mạc miệng trong nghiên cứu này so với mẫu đàm còn tương đối thấp, tuy nhiên còn nhiều điểm trong nghiên cứu này có thể cải thiện thêm khả năng phát hiện vi khuẩn như tăng số mẫu phết niêm mạc miệng. Chuẩn hóa khâu lấy mẫu và lấy mẫu sớm để tránh các hoạt động như ăn uống, vệ sinh răng miệng làm giảm mật độ vi khuẩn.

Nghiên cứu của chúng tôi còn một số hạn chế như số lượng mẫu chưa lớn và chỉ thực hiện trên đối tượng là người trưởng thành trong khi việc nghiên cứu trên một số đối tượng gặp khó khẳn trong việc ho, khạc đàm hoặc có mật độ vi khuẩn thấp như trẻ nhỏ, người già suy kiệt, người nhiễm HIV/AIDS cũng thực sự cần thiết.

\section{KẾT LUÂN}

Kết quả nghiên cứu cho thây có thể phát hiện DNA vi khuẩn lao trong mẫu phết niêm mạc miệng bằng kỹ thuật sinh học phân tử và cho thẩy tiềm năng để có thể sử dụng như một mẫu bệnh phẩm mới để bổ sung cho mẫu bệnh phẩm đàm để tăng tỷ lệ xác định bằng chứng vi khuẩn học một cách không xâm lấn và kịp thời.

\section{TÀI LIÊU THAM KHẢO}

1. Oberhelman. Richard A, Soto-Castellares. Giselle, Gilman. Robert $H$, et al. (2010), "Diagnostic approaches for paediatric tuberculosis by use of different specimen types, culture methods, and PCR: a prospective case-control study", The Lancet infectious diseases, 10 (9), 612-620.

2. Luabeya. Angelique $K$, Wood. Rachel $C$, Shenje. Justin, et al. (2019), "Noninvasive Detection of Tuberculosis by Oral Swab Analysis", Journal of clinical microbiology, 57 (3), e01847-01818.

3. Nicol. Mark P, Wood. Rachel $C$, Workman. Lesley, et al. (2019), "Microbiological diagnosis of pulmonary tuberculosis in children by oral swab polymerase chain reaction", Sci Rep, 9 (1), 1-5.

4. Mateus Sakundarno, Nurjazuli Nurjazuli, Sutopo Patria Jati, et al. (2009), "Insufficient quality of sputum submitted for tuberculosis diagnosis and associated factors, in Klaten district, Indonesia", 9 (1), 16.

5. Shubhada Shenai, Danielle Amisano, Katharina Ronacher, et al. (2013), "Exploring alternative biomaterials for diagnosis of pulmonary tuberculosis in HIV-negative patients by use of the GeneXpert MTB/RIF assay", 51 (12), 4161-4166.

6. R. C. Wood, A. K. Luabeya, K. M. Weigel, et al. (2015), "Detection of Mycobacterium tuberculosis DNA on the oral mucosa of tuberculosis patients", Sci Rep, 5, 8668.

7. Alliny de Souza Bastos, Andressa Rosa Perin Leite, Rubens Spin-Neto, et al. (2011), "Diabetes mellitus and oral mucosa alterations: prevalence and risk factors", 92 (1), 100-105.

8. Lima. Fabiano, Santos. Andrea S, Oliveira. Roberto D, et al. (2020), "Oral swab testing by Xpert ${ }^{\circledR}$ MTB/RIF Ultra for mass tuberculosis screening in prisons", Journal of Clinical Tuberculosis Other Mycobacterial Diseases, 19, 100148. 